\title{
Learners Classification for Personalized Learning Experience in e-Learning Systems
}

\author{
A. JOHN MARTIN ${ }^{1}$ \\ Research Scholar \\ Department of Computer Science \\ Sacred Heart College \\ Tirupattur, India
}

\author{
M. MARIA DOMINIC ${ }^{2}$ \\ Assistant Professor \\ Department of Computer Science \\ Sacred Heart College \\ Tirupattur, India
}

\author{
F. Sagayaraj Francis ${ }^{3}$ \\ Professor \\ Department of Computer Science \\ and Engineering, Puducherry \\ Technological, Pondicherry, India
}

\begin{abstract}
The investigators are inspired by the increasing need and the demand for educational applications and the Learning Management Systems which provide learning objects centered on the learning style of the learners. The technique in which the learners acquire, process, gain the information is unique; these unique characteristics affect their learning process. Hence it is essential to consider and understand the uniqueness among the learners to deliver learner-centric learning objects. The investigators present a system to classify the learners based on the time spent by the learner on learning content of different types. The types of learning content are identified with the percentage of visual, auditory, read/write and kinesthetic in learning object. The prominent learning style called VARK (Visual, Auditory, Read/Write and Kinesthetic) is used to classify the learners. This system classifies the learner and recommends the learning objects based on their learning preference, it also facilitates the faculty members or the content creators to prepare and provide personalized learning objects based on the learning style of the learners.
\end{abstract}

Keywords-Learning style; learning profile; learning objects; eLearning; personalization

\section{INTRODUCTION}

Today, the need for education is the need of the hour in all the sectors. Learning can be defined as a change in the behaviour as a result of experience. The process of learning involves reception and transformation of received information. During the reception process diverse senses are engaged in gathering information from external sources, whereas transformation activity results in internal activities like memorization, inception, inference, pondering and reflection [14]. The acquisition of knowledge and processing the gained knowledge is uneven among learners. There are relative parameters that identify the learning style of a learner. Hence there is a need to adapt strategies to meet the learner preferences to in delivering the learning object whether they are physical or virtual. The process of personalization happens through the investigation of the student's preferences. It is possible to create a model that fulfils the need of the learner based on the information obtained through the investigation [1]-[3].

According to Bruner $[3,15]$, the learner understands the knowledge through four sensory modes, they are Visual (screening pictures, symbols, chars and diagrams), Aural or
Auditory (listening, discussing with peer), Read / Write (reading and writing), and Kinesthetic (use of Hands on exercise, case studies, Demonstrations.). The learning style of a learner is determined by the way in which information is received and processed. Predefined mathematical equations and a set of questionnaires are the traditional ways used to determine learning style of the learners. This may not be appropriate because students prefer more than one mode of learning style because the percentage of time spent on each types of learning object will also vary. To satisfy a given learning style, the teacher or the content creator must use the approach that could meet the needs of diverse learning perspective. Hence the proposed system focuses on the following key contributions.

To recommend a novel but practical approaches to classify the learner based the time spent in each type of learning content to have personalized learning object or learner centred learning objects.

a) To experiment the work through an exemplary case with the data available in Arts and Science College.

The investigation is systematized as follows. Section II describes the State-of-Art of the existing system. Section III provides the proposed works that includes i. architectural design ii. The methodology to classify the learners based on the learner's preference and the experimental result and evaluation of the system have been explained in Section III. Finally the effectiveness of the system and future action plan is discussed.

\section{STATE OF THE ART}

\section{A. Learning Objects}

Any digital form or non-digital form of resource that are used to support learning activity is called Learning Objects. It is a collection of content items used by the learner in the technology assisted learning process. Instances of Learning Objects encompass multimedia content, reference to a web page, visuals, textual content, demonstration and software tools. The Learning objects will have the following characteristics size, duration, interoperability, reusability and multiple context of the content [13]. The significance of the learning object to the learner can be identified by the time spent on a particular learning content type. 


\section{B. Learning Styles}

The learning style shows the way by which a personal collects, process, comprehends and retains the information is referred as learning styles. The learning styles rely upon emotional, cognitive and environmental factors, as well as prior experience of an individual.

There are several models for categorising the learning styles [11]. The popular learning models are discussed in the following sections.

\section{1) David kolbs' learning style model}

This learning style model has four stage, they are [12]

a) Concrete Experience - learning takes place through an exposure or circumstances' encountered, or a through the modification of current exposure.

b) Reflective Observation of the New Exposure learning takes place after gaining experience which enables learner to ask questions and discuss.

c) Abstract Conceptualization - enables the learner to get a new knowledge or a modification of an existing theoretical notion.

d) Active Experimentation - the learner tests their knowledge in the real world and gain new experience.

2) Felder-silverman learning style model: In accordance with Felder and Silverman, there are mixtures of components that make an impact on learning process; like visual/verbal, sensing/intuitive, sequential/ global and active/reflective. As stated by Felder-Silverman the necessary teaching components or elements include visual/verbal, active/passive, sequential/global and concrete/abstract [8]. This model is most appropriate for the courses in engineering education [10].

3) Honey and mumford's learning styles: As mentioned in the work of Kolb, Learning styles were evolved by Peter Honey and Alan Mumford. They identified four explicit learning styles: Activist, Theorist; Pragmatist and Reflector [11]. Honey and Mumford formed a set of questions that supports to identify individual's learning styles which is static in nature.

4) Dunn and dunn learning style model: One of the oldest and most widely used approaches to learning styles is suggested by Rita and Kenneth Dunn (1978, 1992a, 1992b, and Dunn, 1986). According to Dunn and Dunn the learning style of learner classified into five dimensions [6].

- Environmental - The environment influences the learning style of a learner like sound, light, hotness and seating arrangements,

- Emotional - Related motivation, perseverance, and responsibility of the students.

- Sociological - This aspect identifies the preferences of the learning environment and how a learner prefers to learn in pair, what percentage of guidance is.
- Physiological - This is about how a learner responds to the learning task. It brings out other learning styles like visual, auditory and kinesthetic.

- Psychological - It is about how a learner process and respond to information and knowledge.

5) VARK model: In this investigation the researchers have chosen VARK model proposed by Neil D. Fleming [16]. It is one of the best model to classify the learning style. The attributes VARK (Visual, Auditory, Read/Write and Kinesthetic) constitutes Learning Object. The learning style and the learning approach of a learner based on VARK model is shown in the Table 1 .

Understanding the individuals learning preferences can be helpful in the learning process. If a learner understands that visual learning suits the most preferred style, using visual study strategies in conjunction with other learning multimodal style might facilitate the learner to understand, interpret, remember and enjoy the learning.

\section{Traditional Learning vs e-Learning}

Though e-Learning is a full-fledged alternative for the classroom learning but it is not the substitute to the traditional learning. At the same time there exist good and ample evidence that the learner learns as much as online as they do in classroom learning. The major different between traditional learning and e-Learning is, in traditional learning, learners are forced to study based on the syllabus irrespective of their likes and dislikes. In case of e-Learning, learner can filter and choose the content they want to learn. It also provides materials in varies forms like audio, video, animations, presentations and documentation and so on.

The following Table 2 summarizes the difference between traditional and e-Learning [18].

TABLE I. SUMMARY OF VARK LEARNER MODEL

\begin{tabular}{|l|l|l|l|}
\hline S.No & $\begin{array}{l}\text { Learner } \\
\text { Style }\end{array}$ & $\begin{array}{l}\text { Learning approach } \\
\text { towards learning }\end{array}$ & Learning Content \\
\hline 1 & Visual & $\begin{array}{l}\text { Acquisition of } \\
\text { knowledge and } \\
\text { understanding takes } \\
\text { place through the } \\
\text { images, maps, and } \\
\text { graphic representations. }\end{array}$ & $\begin{array}{l}\text { Video, URL, and Power } \\
\text { points slides }\end{array}$ \\
\hline 2 & Auditory & $\begin{array}{l}\text { Learner understands } \\
\text { content through } \\
\text { listening, discussion and } \\
\text { speaking }\end{array}$ & $\begin{array}{l}\text { URL and Power Points } \\
\text { slides with audio, recorded } \\
\text { notes. }\end{array}$ \\
\hline 3 & $\begin{array}{l}\text { Read / } \\
\text { Write }\end{array}$ & $\begin{array}{l}\text { Prefer to learn from the } \\
\text { text }\end{array}$ & $\begin{array}{l}\text { Power Points Slides, Text } \\
\text { documents and PDFs }\end{array}$ \\
\hline 4 & Kinesthetic & $\begin{array}{l}\text { Prefer to learn from } \\
\text { project, practical, hands } \\
\text { on experience, real time } \\
\text { example. Learns by } \\
\text { touch, feel, hold, move } \\
\text { something. }\end{array}$ & $\begin{array}{l}\text { Hands on exercise, case } \\
\text { studies, Demonstrations. }\end{array}$ \\
\hline
\end{tabular}


TABLE II. THE DIFFERENCE BETWEEN TRADITIONAL AND E-LEARNING

\begin{tabular}{|c|c|c|c|}
\hline S.No & Dimension & Traditional Leaning & e-Learning \\
\hline 1 & Discussion & $\begin{array}{l}\text { Teacher discusses } \\
\text { more than the student }\end{array}$ & $\begin{array}{l}\text { Student discusses more } \\
\text { than the teacher }\end{array}$ \\
\hline 2 & $\begin{array}{l}\text { Learning } \\
\text { Process }\end{array}$ & $\begin{array}{l}\text { For whole class, } \\
\text { limited or no } \\
\text { individual study }\end{array}$ & $\begin{array}{l}\text { Learning process takes } \\
\text { place with peer or an } \\
\text { individual }\end{array}$ \\
\hline 3 & $\begin{array}{l}\text { Learning } \\
\text { Objects }\end{array}$ & $\begin{array}{l}\text { Decided by the } \\
\text { teacher according to } \\
\text { the curriculum }\end{array}$ & $\begin{array}{l}\text { Student decides the } \\
\text { learning object formats } \\
\text { based on the learning } \\
\text { preferences. }\end{array}$ \\
\hline 4 & $\begin{array}{l}\text { Emphasis on } \\
\text { Learning } \\
\text { process }\end{array}$ & $\begin{array}{l}\text { Students learn } \\
\text { "What" and not } \\
\text { "how". Teachers are } \\
\text { busy with completing } \\
\text { the syllabus. }\end{array}$ & $\begin{array}{l}\text { Students learn "how" and } \\
\text { less "What" }\end{array}$ \\
\hline 5 & $\begin{array}{l}\text { Teacher's } \\
\text { Role }\end{array}$ & Authority & $\begin{array}{l}\text { Directs student to the } \\
\text { information }\end{array}$ \\
\hline 6 & $\begin{array}{l}\text { Class } \\
\text { Control }\end{array}$ & $\begin{array}{l}\text { Control over the } \\
\text { Learning object and } \\
\text { presentation }\end{array}$ & $\begin{array}{l}\text { Personalization on the } \\
\text { learning object and } \\
\text { presentation }\end{array}$ \\
\hline
\end{tabular}

D. Identification of Learning Styles

The memorization and processing of information by an individual is known as learning style [17]. There are numerous learning styles models, each offer diverse representation and classification with the types of learning. Every individual would have a unique learning style which is a significant attribute to provide personalized learning environment and to accomplish learning satisfaction [4,7,9]. Hence researchers have turned up to categorize the learners based on their learning style [19] since 1940s.

A survey was conducted to the engineering students; questions were based on Index of Learning styles proposed by Felder-Silverman, it was conducted in the year 2016 on 175 students studying MS programming in engineering [12]. A research had been conducted for the classification of learners' style with the VARK questionnaire from a sample group. [2]

Several studies have been done in the field of identification or prediction of learning styles majority of the studies have used survey methods where set of questionnaires were framed and the outcome of the survey shown as a result. Questionnaires were framed based on VARK learning style proposed by Flemming and Miles (1992) the same was used to predict the learning style desire of the engineering students at Atlm University [5].

The researchers have chosen the VARK model for the investigation to help educators/trainer/content creator to recognize individuals learning style to improve the learning process. VARK model unquestionably defines 4 learning styles i.e. visual, auditory, read/write and kinaesthetic. When the learning objects created by them would consist of content types Visual, Auditory, Read/Write and Kinesthetic. These attributes motivated the researchers to choose this model.

There are classifications techniques have been tried out to classify learning styles with a range of learning style models. These techniques sequence the learning activities and observe the learners behaviours with the system [20-22]. According to Dung, the courses are comprised of several topics with different learning contents which are referred as learning objects. The learning objects are labelled based on the Felder and Silverman learning styles and not based on the percentage of the type of learning content in the Learning Object. [23]. In the proposed system classification is done dynamically based the time spent in each type of learning content and not based on the learning sequence which is fixed by the course teacher. Its objective is to provide learner centred learning objects.

\section{PROPOSED WORK}

People are very much interested to know things day by day. Many platforms like web pages, videos, audio messages, illustrations and social media and so on play vital role in knowledge acquisition and sharing. e-Learning provides great opportunities to widen our knowledge through various methods. It may vary depends on user, need, task, subject and content type. The teacher, developer or content creator must take them into consideration while developing e-Learning applications and the learning objects. While developing eLearning application or the learning content, one should clearly identify the content type. The type of learning content is one of the major attributes which should be personalized based on the learner preferred learning content type. Though there are different kinds of learning materials available in eLearning, it is necessary to provide an appropriate content according to the learning style of the learner.

\section{A. Architectural Design}

A schematic representation is shows in Fig. 1. The system consists of two units: User Profiling and classification of learning style of the learner. The general interpretations of these units are given below.

1) User profiling unit: Profile is a unique trait which substantiates the success of learner in the learning activities. The profile of a learner presents the details of individual learner. The main objective of this unit is to pull together the data about the learner's behaviours in accessing the learning objects. As the learner enters to access the learning content through LMS or any educational App, the user profiling unit observes and collects the data including the number of learning objects visited, the time spent on each learning objects. The learning objects visited by the learner may be of any resource types like PPT, PDF, Demonstration, URL, Video, Audio, Images etc. Each Learning Objects are identified by its Id number and every learning object will have certain percentages of content type like Visual, Auditory Read/Write and Kinesthetic.

2) Data pre-processing: The time spent by the learner in each learning object is converted into percentage of time. So that learning content and the learning object are in the percentage.

3) Classification method: The normalized is processed for classification. The learner's pre-dominant learning preference is identified based on the time spent on each type of learning content. This facilitates the content creator to create based on the learner preferred content type. 


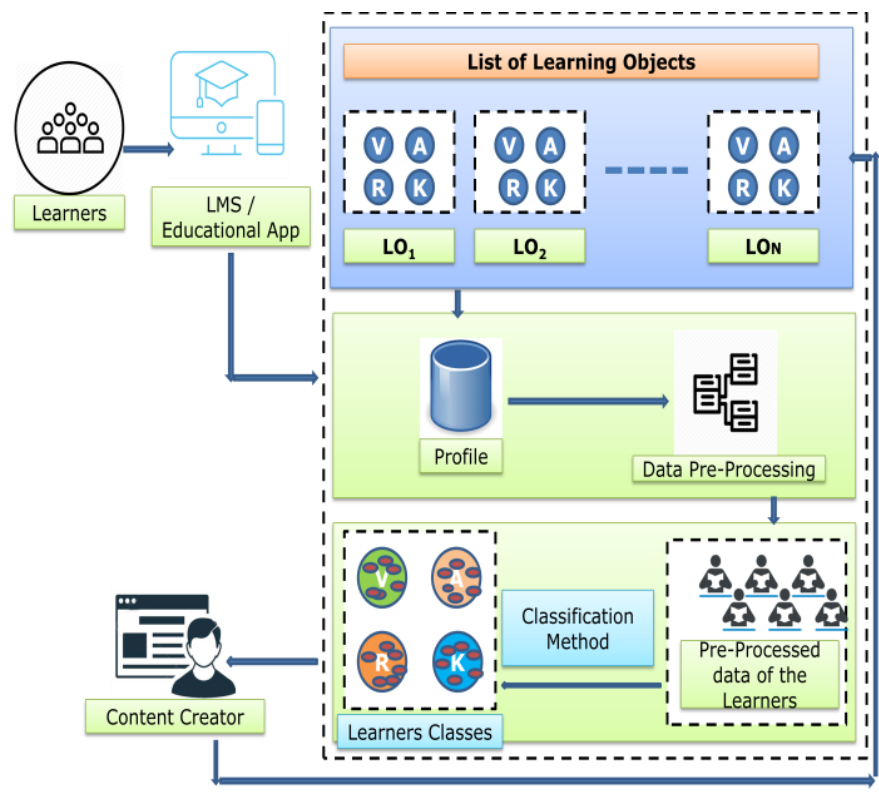

Fig. 1. Schematic Representation of Classification of Learner.

\section{B. Methodology}

The learner preferred learning style is identified as follows. As mentioned earlier the learning content is provided to the learner. The Learning Object consists of certain percentage of learning content type like Visual, Auditory, Read/Write and Kinesthetic.

$$
L . O=\left\{l o_{x} \in\left[l_{\% v}, l_{\% a}, l o_{\% r w}, l o_{\% k},\right]\right\}, x=1,2,3, \ldots . n
$$

Where,

\section{L.O is the collection of Learning Objects}

lo is the Learning Object with the vector of percentage of learning objects of type that are identified by the learning object id, $\mathrm{x}=1,2 \ldots \mathrm{n}$

$\% \mathrm{v}$ is the percentage of Visual Content,

$\%$ a is the percentage of Auditory Content

\%rw is the percentage of Read/Write Content and

$\% \mathrm{k}$ is the percentage of Kinesthetic Content.

For a given learning object the time spent by the learner on learning content is recorded in the profile. Based on the data collected from the profile of learner, the learner's preferred learning style is identified.

$L=\left\{l_{y} \in\left(l_{\% v}, l o_{\% a}, l_{\%} r w, l_{\% k}\right)\right\}, y=(1,, 2,3, \ldots . . n)$

Where,

$L$ is the list of Learner who access the learning Objects

$l$ is a learner who is identified by the user-id, $\mathrm{y}=1,2,3, \ldots \mathrm{n}$.

lo $_{\mathrm{tv}}$ is the time spent by the learner on visual content

$\mathrm{lo}_{\mathrm{ta}}$, is the time spent by the learner on auditory

$\operatorname{lot}_{\mathrm{rw}}$, is the time spent by the learner on Read/Write and $\mathrm{lo}_{\mathrm{tk}}$ is the time spent by the learner on kinaesthetic content

\section{Methodology used in Classification of Learners}

The steps to classify the learners are given below:

1) The learner's user-id and the learning content-id visited by the learner are observed. The following value are tabulated

a) the percentage of learning content in each Learning Object (L.O) lo $\%$ v, lo\%a, lo \%rw, lo \% and

$\operatorname{lot}_{\mathrm{rw}}, \mathrm{lo}_{\mathrm{tk}}$

b) the time spent by the learner in each $\mathrm{LO} \mathrm{lo}_{\mathrm{tv}}, \mathrm{lo}_{\mathrm{ta}}$,

2) The time spent by the learner is normalized by converting it to percentage using the following equations.

$$
\begin{aligned}
& T_{-} V=\left(l o_{t v} / \sum_{i=1}^{t} t=l o_{t v}+l o_{t a}+l o_{t r w}+l o_{t k}\right) * 100 \\
& T_{-} A=\left(l o_{t a} / \sum_{i=1}^{t} t=l o_{t v}+l o_{t a}+l o_{t r w}+l_{t k}\right) * 100 \\
& T_{-} R W=\left(l o_{t r w} / \sum_{i=1}^{t} t=l o_{t v}+l o_{t a}+l o_{t r w}+l o_{t k}\right) * 100
\end{aligned}
$$

$T_{-} K=\left(l o_{t k} / \sum_{i=1}^{t} t=l o_{t v}+l o_{t a}+l o_{t r w}+l o_{t k}\right) * 100$

Where,

' $\mathrm{i}$ ' is the time spent by the learner in an hour $(\mathrm{t})$.

$T_{-} V$ is the percentage of time spent by the learner on visual content

$T \_A$ is the percentage of time spent by the learner on auditory content

$T \_R / W$ is the percentage of time spent by the learner on Read/ Write content

$T \_K$ is the percentage of time spent by the learner on Kinesthetic content

3) The learner's Predominant learning style is obtained from the following equation

$$
\operatorname{L.S}_{j}(\bar{X})=\operatorname{Max}\left[\left\{\frac{\sum l o_{t v_{i}}}{N}, \frac{\sum l o_{t a_{i}}}{N}, \frac{\sum l o_{t r w_{i}}}{N}, \frac{\sum l o_{t k_{i}}}{N}\right\}\right]
$$

Where,

$i=1,2,3, \ldots . N$

(the numberof learning objectsvisited by thelearner)

$j=1,2,3, \ldots M$ (thenumber of users)

The maximum value gives the predominant learning style of the learner.

4) The learning content effect factor is applied in the learning style

$L S_{f}=\frac{L . S}{L . O}$ 
Where,

L.O is the Learning Objects

L.S is the predominant Learning Style of the Learner.

L.S $S_{\mathrm{f}}$ is the learning style of the learner based on effect factor of the learning content.

\section{Experimental Results and Discussion}

The usability of the designed system is evaluated by taking 50 Learning Objects with the defined percentage of VARK content and these learning contents are identified with unique Ids. 250 undergraduate students of all gender from different departments are involved in the experiment and the amount of time spent in each learning content by the 250 learners is tabulated. A snapshot of Percentage of learning content type of Learning Object along with id numbers is shown in the table 3 .

Where,

$L C I D$ is the Learning Content Identification Number

$\%$ Visual is the percentage of Visual Content

$\%$ Auditory is the percentage of Auditory Content

$\%$ Read/Write if the percentage of Read/Write Content

$\%$ Kinesthetic is the percentage of Kinesthetic Content.

The time given for a learner is 60 minutes for a content chosen by the learner. A learner can choose Learning Object of his / her interest. The amount of time spent by the learner in each learning content for a week is tabulated. A snapshot of the dataset is shown in the Table 4.

TABLE III. A SNAPSHOT OF PERCENTAGE OF LEARNING CONTENT TYPE IN LEARNING OBJECT

\begin{tabular}{|c|c|c|c|c|c|}
\hline $\begin{array}{l}\text { LC } \\
\text { ID }\end{array}$ & $\begin{array}{l}\text { User } \\
\text { ID }\end{array}$ & $\begin{array}{l}\% \\
\text { Visual }\end{array}$ & $\begin{array}{l}\% \\
\text { Auditory }\end{array}$ & $\begin{array}{l}\% \\
\text { Read/Write }\end{array}$ & $\begin{array}{l}\% \\
\text { Kinesthetic }\end{array}$ \\
\hline 16 & $\begin{array}{l}\text { User21 } \\
0\end{array}$ & 30 & 21 & 8 & 56 \\
\hline 13 & $\begin{array}{l}\text { User23 } \\
2\end{array}$ & 62 & 23 & 64 & 99 \\
\hline 34 & User8 & 38 & 73 & 91 & 25 \\
\hline 44 & $\begin{array}{l}\text { User14 } \\
2\end{array}$ & 35 & 70 & 48 & 11 \\
\hline 50 & $\begin{array}{l}\text { User14 } \\
8\end{array}$ & 4 & 66 & 27 & 27 \\
\hline 3 & User17 & 44 & 35 & 29 & 79 \\
\hline 16 & $\begin{array}{l}\text { User24 } \\
1\end{array}$ & 26 & 82 & 19 & 9 \\
\hline 20 & $\begin{array}{l}\text { User23 } \\
8\end{array}$ & 11 & 42 & 10 & 14 \\
\hline 17 & $\begin{array}{l}\text { User21 } \\
7\end{array}$ & 58 & 1 & 62 & 38 \\
\hline 31 & $\begin{array}{l}\text { User20 } \\
3\end{array}$ & 42 & 47 & 4 & 15 \\
\hline 15 & User64 & 82 & 55 & 81 & 90 \\
\hline 6 & User96 & 40 & 39 & 46 & 52 \\
\hline 20 & $\begin{array}{l}\text { User18 } \\
3\end{array}$ & 49 & 32 & 54 & 45 \\
\hline
\end{tabular}

TABLE IV. A SNAPSHot of AMOUNT OF Time SPENT By LEARNING ON EACH CONTENT TyPE

\begin{tabular}{|c|c|c|c|c|c|c|c|c|c|}
\hline LC ID & User ID & $\%$ Visual & $\mathbf{T}_{-} \mathbf{V}$ & \% Auditory & T_A & $\%$ Read/ Write & $\mathbf{T}_{-} \mathbf{R} / \mathbf{W}$ & $\%$ Kinesthetic & T-K \\
\hline 16 & User 210 & 30 & 26 & 21 & 2 & 8 & 1 & 56 & 44 \\
\hline 13 & User232 & 62 & 4 & 23 & 16 & 64 & 33 & 99 & 37 \\
\hline 34 & User8 & 38 & 51 & 73 & 53 & 91 & 25 & 25 & 4 \\
\hline 44 & User142 & 35 & 56 & 70 & 59 & 48 & 6 & 11 & 20 \\
\hline 50 & User148 & 4 & 23 & 66 & 43 & 27 & 52 & 27 & 40 \\
\hline 3 & User17 & 44 & 57 & 35 & 43 & 29 & 14 & 79 & 1 \\
\hline 16 & User241 & 26 & 39 & 82 & 37 & 19 & 1 & 9 & 36 \\
\hline 20 & User238 & 11 & 35 & 42 & 14 & 10 & 31 & 14 & 2 \\
\hline 17 & User217 & 58 & 18 & 1 & 31 & 62 & 24 & 38 & 44 \\
\hline 31 & User203 & 42 & 12 & 47 & 25 & 4 & 3 & 15 & 25 \\
\hline 15 & User64 & 82 & 33 & 55 & 60 & 81 & 12 & 90 & 6 \\
\hline 6 & User96 & 40 & 22 & 39 & 39 & 46 & 16 & 52 & 59 \\
\hline 20 & User183 & 49 & 28 & 32 & 59 & 54 & 32 & 45 & 55 \\
\hline
\end{tabular}


TABLE V. TIME SPENT BY THE LEARNER

\begin{tabular}{|l|l|l|l|l|l|l|l|l|l|l|l|}
\hline LC ID & User ID & \% Visual & T_V & \% Auditory & T_A & \% Read /Write & T_R/W & \% Kinesthetic & T_K & Total \% LC & Total \% Time \\
\hline 16 & User1 & 29.86 & 24.44 & 31.25 & 30.00 & 34.38 & 8.89 & 4.51 & 36.67 & 100 \\
\hline 13 & User1 & 22.92 & 13.00 & 7.11 & 14.00 & 32.41 & 32.00 & 37.55 & 41.00 & 100 \\
\hline 34 & User10 & 34.00 & 42.86 & 8.67 & 11.11 & 26.67 & 34.13 & 30.67 & 11.90 & 100 \\
\hline 44 & User10 & 40.52 & 52.13 & 37.25 & 17.02 & 14.38 & 5.32 & 7.84 & 25.53 & 100 \\
\hline 50 & User10 & 29.96 & 19.13 & 34.41 & 24.35 & 12.55 & 41.74 & 23.08 & 14.78 & 100 \\
\hline 3 & User10 & 29.33 & 32.26 & 28.37 & 40.32 & 18.75 & 0.81 & 23.56 & 26.61 & 100 \\
\hline 16 & User100 & 58.62 & 20.00 & 8.05 & 10.00 & 8.05 & 20.00 & 25.29 & 50.00 & 100 \\
\hline 20 & User100 & 15.74 & 18.67 & 43.65 & 27.33 & 36.04 & 24.00 & 4.57 & 100 & 100 \\
\hline 17 & User100 & 11.76 & 16.26 & 45.10 & 14.63 & 31.37 & 41.46 & 11.76 & 27.64 & 100 \\
\hline 31 & User100 & 5.19 & 35.58 & 7.14 & 14.11 & 61.04 & 14.11 & 26.62 & 36.20 & 100 \\
\hline 15 & User100 & 33.60 & 41.26 & 18.80 & 8.39 & 14.00 & 34.97 & 33.60 & 100 \\
\hline
\end{tabular}

TABLE VI. PREDOMINANT LEARNING STYLE

\begin{tabular}{|c|c|c|c|c|c|}
\hline LC ID & User ID & T-V & T-A & T-R/W & T_K \\
\hline 16 & \multirow{5}{*}{ User100 } & 20.00 & 10.00 & 20.00 & 50.00 \\
\hline 20 & & 18.67 & 27.33 & 24.00 & 30.00 \\
\hline 17 & & 16.26 & 14.63 & 41.46 & 27.64 \\
\hline 31 & & 35.58 & 14.11 & 14.11 & 36.20 \\
\hline \multirow[t]{3}{*}{15} & & 41.26 & 8.39 & 34.97 & 15.38 \\
\hline & Learner Style (LS) of User100 & 26.35 & 14.89 & 26.91 & 31.84 \\
\hline & \% of Learning Content (LC) Chosen by User100 & 24.98 & 24.55 & 30.10 & 20.37 \\
\hline Total L.O (5) & Impact of L.O on L.S (L.S/L.O) & 1.05 & 0.61 & 0.89 & 1.56 \\
\hline
\end{tabular}

Where,

$T_{-} V$ is the time spent by the learner on Visual Content

$T \_A$ is the time spent by the learner on Auditory Content

$T \_R / W$ is the time spent by the learner on Read / Write Content

$T \_K$ is the time spent by the learner on Kinesthetic Content

The learners are grouped based on the learning content visited by the learner and the amount of time spent by them is recorded and the data is normalized i.e. time is converted to the percentage. Table 5 gives the details of percentage time spent by three learners namely User1, User10 and User100.

From the table 5 the learner's predominant learning style is classified. For user100, the number of learning content visited is 5 and the time spent in percentage on each learning content is shown in the Table 6.

The result shows that the predominant learning style of User100 is Kinesthetic. This gives an idea to the teacher and content creator to create the learner preferred learning content. The result also shows that the amount of learning content type influences the learning style.

The Fig. 2 shows the classification of learning style of first 25 users. Here we observe that in the absence of learner's predominant learning content type then the learner may be given the next predominant learning content type.

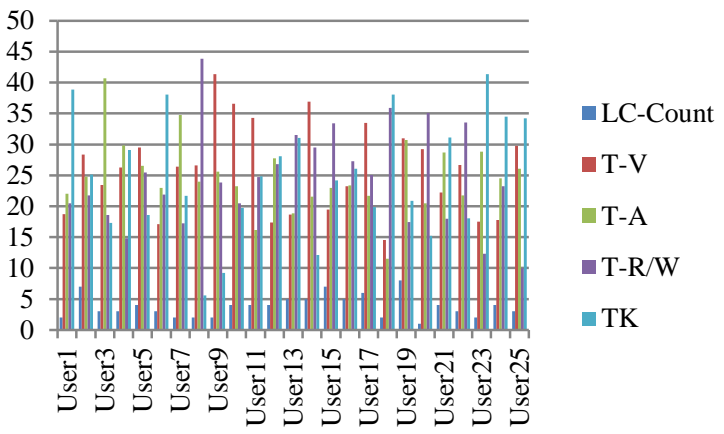

Fig. 2. Classification of Learning Style. 
The classification of learners based on the impact factor of the availability of the percentage learning content type is shown in the Fig. 3.

The Fig. 4 shown below gives the clustering of individual learner i.e. number of learners belongs to Visual, Auditory, $\mathrm{Read} / \mathrm{Write}$ and Kinesthetic style based on the time spent by them in the learning content type.

The Fig. 5 shown below represents the clusters of learners based on the impact factor of the learning content.

From this we observe that most of the learners of the chosen group belong to the kinaesthetic style of learners who prefer learning content in the forms of hands on exercise, case studies and demonstrations.

\section{E. Future Work}

The proposed research work and the use of VARK learning style as designed, it did not account for confounding factors such as socioeconomic status, specialization, race, culture, domicile etc. Also the number of learning content visited by the learner is highly variable, hence a weighted average on learning content count should be considered.

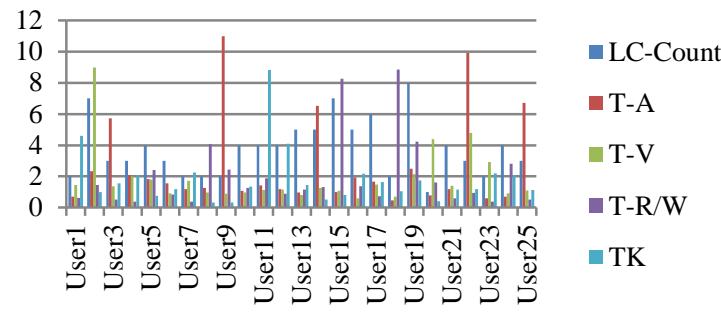

Fig. 3. Classification based on the Impact Factor of the Availability of the Percentage Learning Content Type.

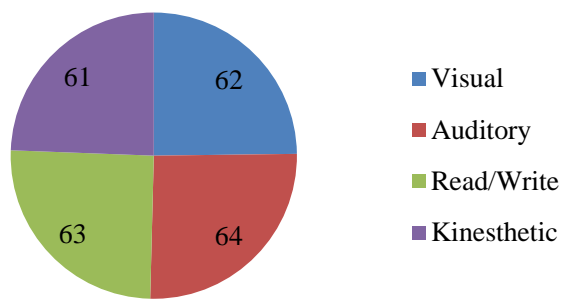

Fig. 4. Learners Cluster based on Time Spent on Learning Content.

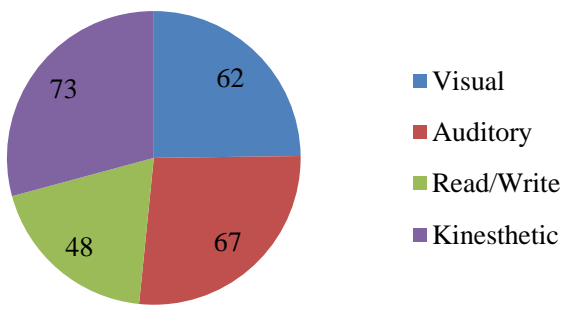

Fig. 5. Learners Cluster based on Learning Content.

\section{CONCLUSION}

It is true that e-Learning environment plays a significant role in modern education. Content creators are consistently working on preparing the Learning Objects in different formats for personalized learning. One of the important features of recent LMS is to provide personalized learning object. It is a fact that the learners would have a joyful learning experience when the LMS is able to provide the learner centred learning styles and the preferred learning objects. Hence, the investigators have proposed, designed and experimented, a novel approach in the classification of learners based on the learners' profile. When a learner enters into a new course, new semester their profile is dynamically analyzed and their learning style is classified which will facilitate the content creator to provide the learner centred learning objects. This process of classification of learner reveals that there is a high impact of learning style for the individuals to perform well in academic activities and gain higher satisfaction level.

\section{REFERENCES}

[1] Akhras, N, F, and Self, A, J, "Modeling the Process, not the Product of Learning", Computer as Cognitive Tools - No More Walls, pp 3- 28.

[2] Beesuda Daoruang, Charun Sanrach, The Learning Material Classified Model Using VARK Learning Style, The Impact of the 4th Industrial Revolution on Engineering Education (pp.505-513), March 2020.

[3] Bruner JS .(1967). Towards a Theory of Instruction, Cambridge: Harvard University Press. Retrieved from http://www.hup. harvard.edu/catalog.php?isbn=9780674897014.

[4] K. Crockett, A. Latham, D. Mclean; J.O'Shea, (2013),A fuzzy model for predicting learning styles using behavioral cues in a conversational intelligent tutoring system, IEEE International Conference on Fuzzy Systems (FUZZ), 2013, pp: $1-8$.

[5] Burcu Devrim Ictenbas, Hande Eryilmaz, "Determining Learning Styles of Engineering Students to Improve the Design of a Service Course", Procedia - Social and Behavioral Sciences (Volume 28 2011).

[6] Carma Daouk, Effects of Dunn and Dunn Learning Styles Model on Achievement and Motivation: A Case Study, LEBANESE AMERICAN UNIVERSITY, School of Arts and Sciences October 2013.

[7] Coffield, F. et al, "Learning styles and pedagogy in post-16 learning. A systematic and critical review", Learning and Skills Research Centre, London, 2004.

[8] Felder, R., and Silverman, L., (1988). Learning and teaching styles in engineering education. Engineering Education, 87(7), 674-684.

[9] Harold Pashler, Mark McDaniel, Doug Rohrer, and Robert Bjork, Learning Styles: Concepts and Evidence, Psychological Science in the PUBLIC INTEREST, Volume 9 Number 3 December 2008.

[10] Honey P and Mumford A (1992). The manual of learning styles. Maidenhead: Peter Honey Publications.

[11] http://www2.le.ac.uk/departments/gradschool/training/resources/teachin $\mathrm{g} /$ theories/honey-mumford).

[12] Index of Learning Styles Questionnaire, https://www.webtools. ncsu.edu/learningstyles/

[13] Kolb, D.A. (1984). Experiential learning: experience as the source of learning and development (11th ed). New Jersey-Hall.

[14] Learning. Retrieved from http:// en.wikipedia.org/wiki/Learning

[15] Norasmah Othmana , Mohd Hasril Amiruddinb , (2010). Different Perspectives of Learning Styles from VARK Model, International Conference on Learner Diversity.

[16] Norman G (2009). When will learning style go out of style? Adv Health Sci Educ Theory Pract. 14:1-4. doi: 10.1007/s10459-009-9155-5.

[17] R. M. Felder and J. Spurlin (2005), Applications reliability, and validity of the Index of Learning Styles. International Journal of Engineering Education, vol. 21, no. 1, pp. 103-112. 
[18] Robert V. Fiermonte and Kelly Bruning, (2001). Harnessing the Power of the Information Age: ELearning - New Frontier of Organizational Training, International Journal of Instructional Technology and Distance Education.

[19] Zhang, L. F. (1999). Relationship between thinking styles inventory and study process questionnaire. Personality and Individual Differences, 29(5), 841-856.

[20] Sheeba, T., \& Krishnan, R. (2019). Automatic detection of students learning style in Learning Management System. In Smart Technologies and Innovation for a Sustainable Future (pp. 45-53). Springer, Cham.
[21] Hasibuan, M. S., Nugroho, L. E., \& Santosa, P. I. (2019). Model detecting learning styles with artificial neural network. Journal of Technology and Science Education, 9(1), 85-95.

[22] Graf, S. (2007). Adaptivity in Learning Management Systems Focussing on Learning Styles. PhD thesis, Vienna University of Technology, 9801086 Neulinggasse 22/12A 1030, Vienna.

[23] Dung, P. Q. (2012). An approach for detecting learning styles in learning management systems based on learners' behaviours. International Conference on Education and Management Innovation, 30. 